\title{
Вибір ефективних фільтрувальних респіраторів. Проблеми і можливості
}

\author{
Сергій Чеберячко ${ }^{*}$; Олег Дерюгін А; Володимир Мірненко ${ }^{\text {; }}$ \\ Наталія Бородіна ${ }^{c}$
А Національний технічний університет «Дніпровська політехніка», проспект Дмитра Яворницького, 19, м. Дніпро, 49005, Україна

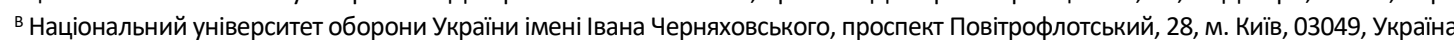 с Білоцерківський інститут неперервної професійної освіти, вул. Леваневська, 54/2, м. Біла Церква, 09100, Україна

Received: July 25, 2020 | Revised: August 16, 2020 | Accepted: August 31, 2020

DOI: $10.33445 /$ sds.2020.10.4.3

\begin{abstract}
Анотація
Метою роботи $\epsilon$ розкриття можливостей для забезпечення вибору якісного фільтрувального респіратора, який відповідає умовам праці і антропометричним параметрам обличчя користувачів. Встановлено, що критичними питаннями для забезпечення надійного захисту користувачів під час виконання професійної діяльності з використанням засобів індивідуального захисту органів дихання, які не розкриті (не відображені) у відповідних нормативних документах $\epsilon$ процедура оцінки ризиків, урахування умов праці, перевірка відповідності півмаски фільтрувального респіратора антропометричним параметрам обличчя користувача, урахування терміну захисної дії фільтрів. Показано, що відповідно нормативних актів організація з оцінки ризиків професійних захворювань як при виборі, так і при експлуатації фільтрувальних респіраторівобов'язок роботодавця, а контроль за сумлінним виконанням рекомендацій по ефективному використанню фільтрувальних респіраторів повинні здійснювати робітники відділів охорони праці підприємства. Запропоновано проводити оцінку ризиків професійних захворювань під час вибору і експлуатації фільтрувальних респіраторів одним із методів згідно 3 вимогами ДСТY IEC/ISO 31010:2013. Надані рекомендації щодо усунення можливих помилок під час цього процесу для зменшення рівня ризику виникнення професійного захворювання. Розроблено нову класифікацію фільтрувальних засобів індивідуального захисту органів дихання, яка дозволяє провести вибір з урахуванням особливостей умов виконуваної роботи. Показано, що за допомогою термографування смуги обтюрації півмаски фільтрувального респіратора можна встановити їі відповідність антропометричними параметрам обличчя користувача. Рекомендується проводити заміну фільтрів, виходячи або із розрахунку терміну захисної дії відповідно до умов праці або використавши фільтри 3 активними/пасивними індикаторами.
\end{abstract}

Ключові слова: засоби індивідуального захисту органів дихання, фільтрувальний респіратор, професійне захворювання, ризик, гранично допустима концентрація шкідливих речовин.

\section{Постановка проблеми}

Сучасні виробничі умови характеризуються високим ступенем індустріалізації й урбанізації, внаслідок чого відбувається постійний контакт 3 різноманітними техногенними чинниками (пил, дим, туман або газ та пара), вміст яких у повітрі робочої зони перевищує гранично допустимі концентрації (ГДК). Захворювання органів дихання асоційовані з інгаляційним мінеральним пилом, насамперед пневмоконіози, які $\epsilon$ невиліковними та мають

\footnotetext{
* Corresponding author: д.т.н., професор, професор кафедри охорони праці та цивільної безпеки, e-mail: sicheb@ukr.net, ORCID: 0000-0003-3281-7157
} 
суттву частку серед професійних захворювань промислових, добувних та ін. підприємств.

За даними останніх оцінок спеціалістів Міжнародної організації праці (МОП) та Всесвітньої організації охорони здоров'я (ВООЗ) кількість смертей, що пов'язані 3 професійними захворюваннями щорічно сягає більше 2 млн випадків. Кожного року у світі реєструється понад 160 млн нових випадків професійних захворювань [1]. Визначено, що основними причинами розвитку професійної патології $€$ помилки у визначенні небезпечних факторів виробничого середовища та оцінки професійних ризиків, використання неефективного обладнання та недосконалість технологічних процесів, неправильне невикористання (небажання/нерозуміння / відмова) засобів індивідуального захисту органів дихання (ЗІЗОД). Відповідно до міжнародного законодавства роботодавець зобов'язаний створити на робочому місці в кожному структурному підрозділі умови праці відповідно вимог чинного законодавства 3 охорони праці. Зокрема, концентрація шкідливих токсичних аеродисперсних частинок (пил, дим, туман), газів і парів в повітрі робочої зони повинна бути менше ГДК, а у випадках, коли рівень розвитку науки і техніки не дозволяє це зробити, роботодавець мусить забезпечити робітників ефективними ЗІзОД - фільтрувальними респіраторами відповідного функціонального призначення (протипиловими, протигазовими або газопилозахисними) [1]. Так, згідно зі Директивою ЕС 89/391 та відповідно до “Мінімальних вимог безпеки і охорони здоров'я при використанні працівниками засобів індивідуального захисту на робочому місці", затверджених наказом Міністерства соціальної політики України від 29 листопада 2018 р. № 1804 роботодавець повинен безкоштовно забезпечити працівників зІзОД.

Вибір і організація правильного використання ЗІзОД також покладена на роботодавця і повинна здійснюватися відповідно до вимог ДСТУ ЕN 529: 2006 “Рекомендації щодо вибору, використання, догляду і обслуговування ЗІЗОД”. Зазначимо, що нормативний документ передбачає використання ЗІзОД тільки в тому випадку, коли забрудненість повітря неможливо зменшити за допомогою інших технічних заходів передбачених у п. 6 цього документа.

\section{Аналіз останніх досліджень та публікацій}

Аналіз літературних даних за останні п'ять років дозволяє зробити висновок, що в Україні досить небагато публікацій присвячених проблемам вибору якісних ЗІЗОД. Зокрема висвітлені задачі із визначення потреб підприємств в використанні ЗІЗОД, загальна інформація щодо правил вибору, де перелічуються вимоги до ЗІЗОД та їх класифікація [2; 3; 4]. Існують певні напрацювання щодо зниження захисних властивостей під час експлуатації фільтрувальних респіраторів [5]. Також зустрічаються публікації стосовно опису тих чи інших даних технічних, ергономічних та експлуатаційних характеристик ЗІзОД [6; 7; 8]. Більшість зарубіжних досліджень, за вказаний період, стосуються розробки захисних пристроїв для забезпечення індивідуального вибору зІЗОД, який передбачає необхідність у дослідженні антропометричних характеристик обличь користувачів, для чого останнім часом широко використовують технологію 3D сканування [9]; побудови 3D дизайну півмаски фільтрувального респіратора за допомогою різноманітного програмного забезпечення [10; 11]; уніфікації конструкцій, 3 різним функціональним призначенням [12-13]; підбору відповідних матеріалів для виготовлення півмаски, наприклад поліфункціональних хемосорбентів для уловлювання токсичних газів та парів $[14 ; 15$, 16]. Однак навіть вказаний підхід потребує доробки. По-перше, щодо врахування параметрів рис обличчя користувачів, які можуть змінюватись за віком, статтю і національністю. Важливо щоб цифрове зображення могло змінюватись, оскільки за відповідними координатами точок 
відбувається моделювання поверхні півмаски фільтрувального респіратора. По-друге, розробки швидких способів перевірки захисних властивостей фільтрувальних респіраторів, на етапі його експлуатації. По третє визначення об'єму фільтрувальних коробок для забезпечення відповідного умовам праці терміну захисної дії. Отже, підсумовуючи проведений аналіз можна зробити висновок про відсутність системних досліджень направлених на забезпечення відповідного вибору зІзОд.

\section{Постановка завдання}

Процедура вибору ефективних ЗІзод, зокрема фільтрувальних респіраторів проводиться у такій послідовності: ідентифікація шкідливих речовин у повітрі робочої зони, оцінка професійних ризиків, обгрунтування вибору (порівняння забруднення середовища із класом захисту ЗІзОД, визначення відповідності ЗІЗОД до умов праці, користувача та ін.) навчання робочих навичкам правильного використання, зберігання і обслуговування [17; 18]. Нажаль, навіть добросовісне виконання відповідної процедури не гарантує ефективний захист органів дихання користувача, оскільки розробники ДСТУ ЕN 529:2006, формалізували стадії вибору фільтрувальних респіраторів, навіть не згадали про те, що їх вибір потрібно здійснювати, перш за все, відповідно до класифікації і умов експлуатації, враховуючи при цьому їх технічні характеристики - i особливості і відмінності антропометричних розмірів обличь у користувачів різних національностей, статі та вікових груп. Останнє тому, що, у разі несумісності півмаски фільтрувального респіратора 3 обличчям користувача, утворюються щілини за смугою обтюрації і відбувається підсмоктування шкідливих токсичних речовин у підмасковий простір. До того ж у стандарті наведено три різних показники, які характеризують захисні властивості ЗІЗОД, однак про «національний» коефіцієнт захисту, за яким рекомендується проводити їх вибір нічого не сказано звідки він береться, як розраховується і як визначається невідомо.

Проблема вибору ефективного фільтрувального респіратора, що відповідає умовам експлуатації, ергономічним і експлуатаційним

\footnotetext{
* фізіологічний поріг больового відчуття знаходиться в межах 4-6 Н. Збільшення його призводить до
}

вимогам, посилюється ще й тим, що досі немає простих i надійних методів визначення щільного прилягання півмаски до обличчя користувача і питомого тиску обтюратора на обличчя по смузі обтюрації; термін захисної дії протиаерозольних респіраторів під час експлуатації визначається за утрудненням диханню, а у випадку протигазових респіраторів - за відчуттям запаху (проте, не вказано, які шкідливі гази можна виявляти за запахом, а які - категорично заборонено). У нормативно-технічній документації не використовується інформація щодо візуальної індикації і інструментального визначення “проскоку" токсикантів крізь протипилові i протигазові фільтри.

Майже нерозкритим питанням, яке потребує серйозного вивчення i широкого розкритяя $\epsilon$ оцінка ризиків, які пов'язані 3 вибором і подальшою експлуатацією - ЗІЗОД, нащо вказують як міжнародні (Директива ЕС 89/391 (стаття 4, 5); ISO 45001), так і вітчизняні (OCSAS 18001:2008, НАОП 0.00-7.17-18) нормативні документи. Відмітимо, що в зазначених документах нічого не сказано, а ні про види ризиків, а ні про те як їх оцінювати

Не визначеним $€$ термін захисної дії ЗІзОД. Навіть для протиаерозольних фільтрів виникають складнощі 3 його встановлення, хоча і надаються рекомендації - за утрудненням дихання (додаток А, ДСТУ EN 529:2006). Однак, на опір фільтрів значно впливає швидкість руху повітря, яка може відрізнятись через фізіологічну будову легень користувача або через важкість виконуваної їм роботи. Може так статись, що в одних і тих самих умовах одним користувачам потрібно декілька фільтрів, а іншим достатньо і одного

здавлювання м'яких тканин і утворення наминів на обличчі користувача. 
фільтра. Ще складніша проблема 3 оцінки терміну захисної дії протигазових фільтрів. Рекомендація ДСТУ EN 529:2006 - за суб'єктивним відчуттям запаху $є$ некоректною, адже користувачів різний органолептичний поріг, при чому існує значна кількість газів без запаху. Також в стандарті не вказано, які шкідливі гази можна виявляти за запахом, а які - категорично «не можна».

Вихід зі цієї ситуації вбачається, в першу чергу, в розробці фільтрів з індикатором закінчення терміну захисної дії. Для протипилових респіраторів він може базуватись на датчику перепаду тиску, для протигазових - на зміні кольору сорбенту, який вступає у реакцію. Також провідні компаніїрозробники ЗІЗОД надають консультації у вигляді розроблених програм для розрахунку терміну захисної дії, які розміщенні на їх сайтах.

Метою даної роботи $€$ розкриття проблем та можливостей для забезпечення вибору якісного фільтрувального респіратора 3 урахуванням оцінки ризиків під час вибору i експлуатації ЗІЗОД, характеру умов праці, відповідності антропометричним параметрам обличчя користувача та терміну захисної дії фільтрів.

Це дослідження проводилося для виявлення небезпечних факторів, які можуть значно погрішити ступінь захисту користувачів фільтрувальних респіраторів для захисту від різних шкідливих аерозолів 3 метою забезпечення ефективного виконання програми респіраторного захисту як частини заходів для збереження їх здоров'я. На основі відкритої інформації з різних джерел це дослідження поєднує відомості про те, що сприяє i що перешкоджає правильному вибору і експлуатації фільтрувальних респіраторів. Спочатку вивчалась доступна література з організації вибору фільтрувальних респіраторів. Потім проводився аналіз можливих шляхів вирішення описаних вище задач.

\section{Виклад основного матеріалу}

Вибір фільтрувального респіратора починається зі збору відомостей про [19-20]:

- умови праці, кліматичні параметри робочого простору, характер робіт;

- фізичні, хімічні й токсичні властивості шкідливої речовини, що містяться в атмосфері робочої зони;

- ГДК шкідливих речовин, що містяться в атмосфері робочої зони;

- значення миттєво-небезпечної концентрації для життя й здоров'я користувача фільтрувального респіратора та ймовірність їі виникнення.

Після виявлення та визначення небезпеки від шкідливих аерозолів їх концентрацій та впливу на здоров'я користувачів на робочому місці, виникає питання у визначенні професійних ризиків для прийнятя рішення щодо обґрунтування вибору ефективного ЗІЗОД. Судячи з нормативних документів [1923] та публікацій [24-28], найбільш просунуті фахівці з безпеки праці усвідомили, що ефективне використання ЗІЗОД можливо лише на підставі одержаних даних щодо ризиків професійних захворювань користувачів, обумовлених помилками при виборі i експлуатації ЗІзод.

Відповідно до вимог ДСТУ OHSAS 18002:2015 - ризик представляє собою комбінацію ймовірності виникнення небезпечних подій і ступеню серйозності їх наслідків. Для його визначення необхідні детальні відомості про умови праці, небезпеки, засоби захисту, контролю, компетентність працівників та інше відповідно до п. 4.3.1.4.2 вище згаданого стандарту. Не вдаючись у подробиці, відзначимо, що у згаданих нормативних документах відсутні роз'яснення щодо походження, вагової оцінки та рекомендацій з усунення або зменшення ризиків професійних захворювань користувачів ЗІзоД. Хоча його оцінку можна проводити різними методами, які описані у ДСТУ IEC/ISO 31010:2013 все ж таки процедура потребує певних роз'яснень. Наприклад, ризик можна оцінити методом "Risk score", який розроблений за Британським стандартом BS8800 (мал. 1). Величину ризику $(R)$ визначають 
в балах за формулою [20]:

$$
R=S \cdot P,
$$

де $S$ - серйозність наслідків; $P$ - ймовірність
У таблиці 1 наведений приклад з визначення

(1) ризику виникнення професійного захворювання на антракоз у гірників. події.

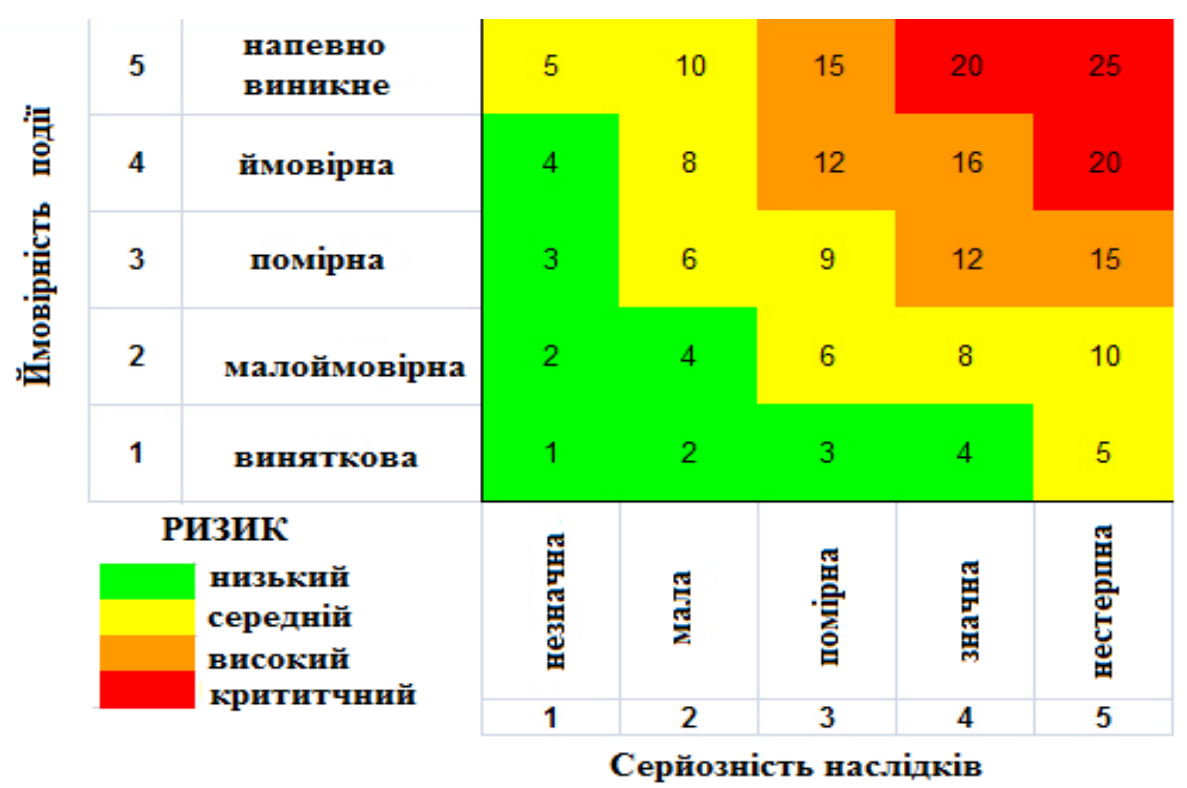

Мал. 1 - Таблиця визначення ризику за методом "Risk score"

Таблиця 1. - Оцінка ризику виникнення професійного захворювання органів дихання гірників, які працюють при запиленості $100 \mathrm{Mr} / \mathrm{M}^{3}$

\begin{tabular}{|c|c|c|c|c|c|c|}
\hline \multirow{2}{*}{ Професія } & Небезпека & \multirow{2}{*}{ Наслідки } & \multicolumn{3}{|c|}{ Базовий ризик } & \multirow{2}{*}{$\begin{array}{c}\text { Категорія } \\
\text { ризику }\end{array}$} \\
\cline { 4 - 6 } & & Наслідків & $\begin{array}{c}\text { Ймовірність } \\
\text { події }\end{array}$ & Ризик & рйість \\
\hline Гірник & Вугільний пил & Антракоз & 5 & 5 & 25 & Критичний \\
\hline
\end{tabular}

Можна оцінити ризик більш складнішим методом “HAZID", який найчастіше використовують на початкових етапах розробки різних проектів. Він відповідає вимогам в області "HSE" (Health and Safety Executive/здоров'я безпеки, навколишнє середовище). Для розрахунків необхідні знання інфраструктури, технологічних операцій, небезпек для здоров'я працівників, можливих аварійних ситуацій та інше. Рівень ризику встановлюється також з урахуванням матриці «ймовірність - важкість наслідків» за визначеною шкалою. Фрагмент робочої таблиці оцінки ризиків за описаним методом наведено в табл. 2.

Відповідно [25], фактори, що впливають на ефективність використання фільтрувальних ЗІЗОД, можна підрозділити на дві групи: І фактори, які пов'язані з помилками при виборі ЗІзОД, II - фактори, які пов'язані з невмілою або/і безвідповідальною експлуатацією зІзоД. Тому виникає потреба у детальному їх аналізі для визначення критичних, з метою їх усунення або зменшення до прийнятного рівня. Найбільш вірогідні небезпеки пов'язані 3 вибором і експлуатацією респіраторів та рекомендації щодо їх зменшення наведені в таблицях 3, 4. Зазначимо, що організація оцінки ризиків професійних захворювань як при виборі, так і при експлуатації респіраторів обов'язок роботодавця, а контроль за сумлінним виконанням рекомендацій по ефективному використанню респіраторів повинні здійснювати робітники відділів охорони праці.

Зазначимо, що організація оцінки ризиків професійних захворювань як при виборі, так i при експлуатації респіраторів - обов'язок роботодавця, а контроль за сумлінним виконанням рекомендацій по ефективному 


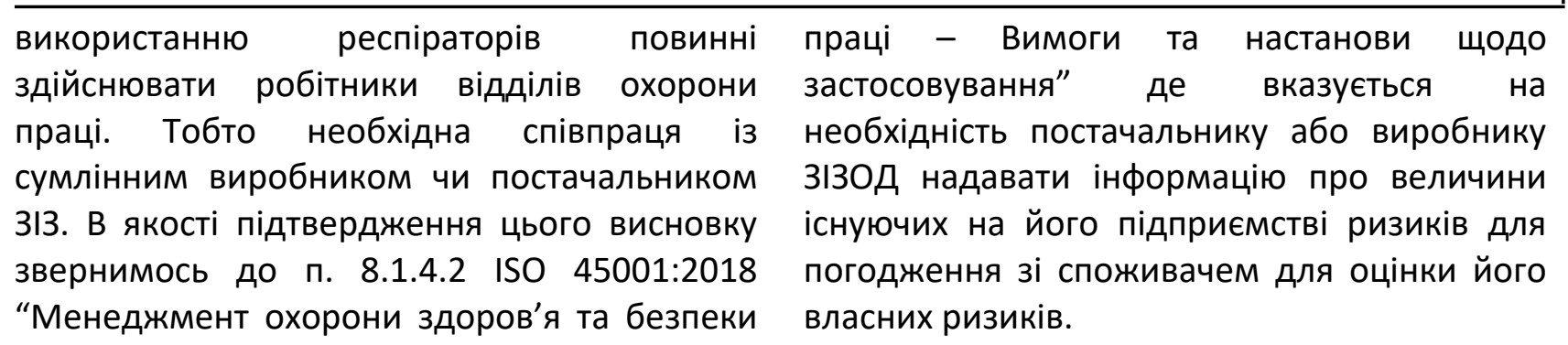

Таблиця 2. - Фрагмент робочої відомості розрахунку ризиків методом «HAZID»

\begin{tabular}{|c|c|c|c|c|c|c|}
\hline № & $\begin{array}{c}\text { Небезпечний } \\
\text { фактор }\end{array}$ & $\begin{array}{c}\text { Наслідки впливу } \\
\text { небезпечного } \\
\text { фактору }\end{array}$ & Загрози & $\begin{array}{c}\text { Профілактичні } \\
\text { заходи }\end{array}$ & Ризик & Зауваження \\
\hline \multicolumn{7}{|c|}{ Небезпеки для здоров'я } \\
\hline 1. & $\begin{array}{l}\text { Недостатній } \\
\text { вміст кисню }\end{array}$ & $\begin{array}{c}\text { Поява задихання, } \\
\text { серцебиття, } \\
\text { запаморочення, } \\
\text { смерть }\end{array}$ & Персонал & $\begin{array}{c}\text { Провітрювання, } \\
\text { контроль вмісту } \\
\text { кисню, розробка } \\
\text { маршрутів на } \\
\text { свіжому потоку } \\
\text { повітря }\end{array}$ & 2 & $\begin{array}{c}\text { Небезпека висока } \\
\text { призводить до } \\
\text { смерті }\end{array}$ \\
\hline 2. & $\begin{array}{c}\text { Вугільний } \\
\text { пил }\end{array}$ & $\begin{array}{c}\text { Виникнення } \\
\text { захворювань } \\
\text { системи дихання } \\
\text { (силікоз, рак } \\
\text { легенів). }\end{array}$ & Персонал & $\begin{array}{c}\text { Провітрювання, } \\
\text { впровадження } \\
\text { систем } \\
\text { знепилювання, } \\
\text { колективного } \\
\text { захисту, розробка } \\
\text { програми } \\
\text { респіраторного } \\
\text { захисту }\end{array}$ & 1 & $\begin{array}{c}\text { Небезпека } \\
\text { висока, } \\
\text { працівники } \\
\text { постійно з } \\
\text { находяться у } \\
\text { небезпечній зоні, } \\
\text { концентрація } \\
\text { перевищує Гдк }\end{array}$ \\
\hline
\end{tabular}

Вибір зІзоД за характером виконуваних робіт роботодавець обов'язково повинен здійснювати з урахуванням їх класифікації відповідно до чинних в Україні національних стандартів [28-30]. Існує два таких нормативних документа. У першому (ДСТУ 7239:2011 “Засоби індивідуального захисту. Загальні вимоги та класифікація") вказується, що ЗІЗОД бувають фільтрувальні, ізолювальні та зі змінною маскою зварювальника. Тоді як у другому (ДСТУ ЕN 133:2005 “Засоби індивідуального захисту органів дихання. Класифікація") ЗІзОД поділяють ще й за лицевими частинами, фільтрами та системою подавання повітря у підмасковий простір. Лицеві частини можуть бути масками, 3 фільтрувальною лицевою частиною, капюшоном, шоломом тощо. Фільтри, за ефективністю, поділяють на три класи низького, середнього, високого захисту. За подаванням повітря у підмасковий простір
зІзОД бувають самовсмоктувальні і 3 примусовою подачею повітря. Вказана класифікація ЗІзОД неповній мірі висвітлює все їх різноманіття за конструктивними особливостями та функціональним призначенням, що значно ускладнює вибір через відсутність розуміння впливу виробничих завдань та складових частин: півмаски, наголів'я обтюратора, клапанного блоку на фізіологічний стан людини його працездатність. Кожен з цих елементів в кінцевому випадку впливає на ефективність захисту користувача, яка визначається цілою низкою компонентів. Виходячи з існуючої класифікації занадто складно підібрати фільтрувальний пристрій, який врахував необхідність надійного кріплення півмасок в залежності від вимог до рухомості або темпу роботи, коли респіратор може сповзти 3 обличчя і збільшити надходження шкідливої речовини крізь щілини за смугою 


\begin{tabular}{llll}
\hline обтюратора. & Також важко забезпечити & конструктивних особливостей клапанів \\
ізолювальні & властивості респіраторів без & видихання, обтюратора та наголів'я. \\
розуміння & властивостей матеріалів і
\end{tabular}

Таблиця 3. - Рекомендації щодо зменшення ризиків професійних захворювань внаслідок помилок при виборі ЗІЗОД

\begin{tabular}{|c|c|c|}
\hline \multicolumn{2}{|c|}{ Помилки } & \multirow{2}{*}{$\begin{array}{c}\text { Рекомендації щодо зменшення } \\
\text { ризиків професійних захворювань }\end{array}$} \\
\hline Найменування & Наслідки & \\
\hline $\begin{array}{l}\text { 1. Фільтрувальний респіратор не } \\
\text { відповідає функціональному } \\
\text { призначенню }\end{array}$ & $\begin{array}{l}\text { Не забезпечується } \\
\text { нормативний захист }\end{array}$ & $\begin{array}{c}\text { Ужити фільтрувальний респіратор } \\
\text { відповідного типу і класу }\end{array}$ \\
\hline $\begin{array}{l}\text { 2. Фільтрувальний респіратор } \\
\text { вибрано за призначенням, але } \\
\text { не визначено антропометричні } \\
\text { особливості обличчя }\end{array}$ & $\begin{array}{c}\text { Проникнення у } \\
\text { підмасковий простір } \\
\text { пилу крізь щілини між } \\
\text { обтюратором і обличчям }\end{array}$ & $\begin{array}{c}\text { Притиснути респіратор до обличчя, } \\
\text { не перевищуючи межі пито-мого } \\
\text { тиску. Ужити респіратор зі змінною } \\
\text { геометрією смуги обтюрації. }\end{array}$ \\
\hline $\begin{array}{l}\text { 3. Фільтрувальний респіратор } \\
\text { вибрано згідно з пп. } 1 \text { і 2, але не } \\
\text { враховано що, концентрація } \\
\text { кисню у повітрі робочої зони < } \\
\text { 18\%; }\end{array}$ & $\begin{array}{c}\text { Головокружіння, } \\
\text { слабкість, збільшення } \\
\text { серцебиття. При вмісті } \\
\text { кисню << 18\% - судоми і } \\
\text { смерть }\end{array}$ & $\begin{array}{c}\text { Вентиляція робочої зони. } \\
\text { Використання ізолюючих ЗІЗОД }\end{array}$ \\
\hline $\begin{array}{l}\text { 4. Фільтрувальний респіратор } \\
\text { вибрано згідно з пп. } 1 \text { і 2, але не } \\
\text { враховано що, рівень } \\
\text { забруднення повітря перевищує } \\
\text { межу безпечного використання } \\
\text { респіратора; }\end{array}$ & $\begin{array}{c}\text { Не забезпечується } \\
\text { нормативний захист } \\
\text { органів дихання }\end{array}$ & $\begin{array}{c}\text { Ужити респіратор відповідного } \\
\text { класу захисту }\end{array}$ \\
\hline $\begin{array}{l}\text { 5. Фільтрувальний респіратор } \\
\text { вибрано згідно з пп. } 1 \text { і 2, але не } \\
\text { враховано що, підвищені } \\
\text { температура і вологість повітря } \\
\text { в атмосфері робочої зоні }\end{array}$ & $\begin{array}{c}\text { Потіння обличчя, } \\
\text { зростання опору дихання }\end{array}$ & $\begin{array}{c}\text { Ужити респіратор з клапаном } \\
\text { видиху або/і водопоглинальним } \\
\text { елементом }\end{array}$ \\
\hline
\end{tabular}

Останнім часом з'явились нові вимоги до фільтрів, які розділили їх на одноразові і багаторазові, що також не відображається в існуючій класифікації. В табл. 5 авторами наведено нову класифікацію ЗІЗОД, яка заповнює існуючі прогалини у вітчизняному законодавстві та дозволяє 3 розумінням розробити послідовність дій при виборі ЗІЗОД. Вона $\epsilon$ першою спробою у розподілі всіх існуючих ЗІзОД за зрозумілим ієрархічним порядком підпорядкування нижчих ланок вищим, починаючи з відділу - фільтрувальні ЗІзОД і закінчуючи різновидом - за ступенем досконалості конструкції фільтрувальних респіраторів або/і їх складових щодо фізіологічних вимог користувачів. Це дозволяє чітко зрозуміти структурну взаємодію різновидів та визначити ступінь розгалуженості можливих варіантів ЗІзОД.

Для прикладу наведемо ключові моменти вибору фільтрувального респіратора для гірника, який працює у видобувному забої 3 концентрацією пилу у робочій зоні $30 \mathrm{mr} / \mathrm{m}^{3}$. Робота виконується при температурі $26^{\circ} \mathrm{C}, 3$ вологістю повітря 95\%, темп роботи інтенсивний.

Спочатку виясняємо, який захисний пристрій нам потрібен: фільтрувальний чи ізолювальний. Вибір залежить від кількості кисню у робочій зоні. Якщо більше $18 \%$ - використовуємо фільтрувальні ЗІзОД. 
Таблиця 4. - Рекомендації щодо зменшення ризиків професійних захворювань внаслідок помилок при експлуатації ЗІЗОД

\begin{tabular}{|c|c|c|}
\hline \multicolumn{2}{|l|}{ Помилки } & \multirow{2}{*}{$\begin{array}{c}\text { Рекомендації щодо } \\
\text { зменшення ризиків } \\
\text { професійних захворювань }\end{array}$} \\
\hline Найменування & Наслідки & \\
\hline $\begin{array}{l}\text { 1. Фільтрувальний респіратор } \\
\text { використовується ненавченими поводженню з } \\
\text { ним користувачем (пристосування, } \\
\text { експлуатація і/або зберігання) }\end{array}$ & $\begin{array}{c}\text { Не } \\
\text { забезпечується } \\
\text { нормативний } \\
\text { захист }\end{array}$ & $\begin{array}{l}\text { Забезпечити обов'язкове } \\
\text { навчання працівників } \\
\text { поводженню з зІзод. }\end{array}$ \\
\hline $\begin{array}{l}\text { 2. Фільтрувальний респіратор використовується } \\
\text { навченими працівниками, але не враховано } \\
\text { умови його експлуатації - можливість } \\
\text { механічного пошкодження і потрапляння води } \\
\text { на фільтрувальну маску }\end{array}$ & $\begin{array}{c}\text { Не } \\
\text { забезпечується } \\
\text { нормативний } \\
\text { захист }\end{array}$ & $\begin{array}{l}\text { Ужити респіратор з } \\
\text { еластомірною маскою }\end{array}$ \\
\hline $\begin{array}{l}\text { 3. Фільтрувальний респіратор використовується } \\
\text { навченими працівниками, але не враховано } \\
\text { умови його експлуатації - збільшення } \\
\text { навантаження та рухливості користувача }\end{array}$ & $\begin{array}{c}\text { Зростання опору } \\
\text { диханню, потіння } \\
\text { обличчя }\end{array}$ & $\begin{array}{l}\text { Ужити фільтрувальний } \\
\text { респіратор з клапаном видиху }\end{array}$ \\
\hline $\begin{array}{l}\text { 4. Фільтрувальний респіратор використовується } \\
\text { навченими працівниками, але не враховано } \\
\text { умови його експлуатації - необхідність } \\
\text { спілкування під час виконання роботи }\end{array}$ & $\begin{array}{c}\text { Не } \\
\text { забезпечується } \\
\text { нормативний } \\
\text { захист }\end{array}$ & $\begin{array}{l}\text { Ужити ЗІЗОД з переговорним } \\
\text { пристроєм }\end{array}$ \\
\hline $\begin{array}{l}\text { 5. Фільтрувальний респіратор використовується } \\
\text { навченими працівниками, але не враховано } \\
\text { умови його експлуатації - використання } \\
\text { фільтрувального респіратора несумісного з } \\
\text { іншим ЗІЗОД }\end{array}$ & $\begin{array}{c}\text { Не } \\
\text { забезпечується } \\
\text { нормативний } \\
\text { захист }\end{array}$ & $\begin{array}{l}\text { Ужити фільтрувальний } \\
\text { респіратор, який } \\
\text { виробляється одним } \\
\text { виробником }\end{array}$ \\
\hline $\begin{array}{l}\text { 6. Фільтрувальний респіратор використо- } \\
\text { вується навченими працівниками, але не } \\
\text { враховано умови його експлуатації - } \\
\text { надпланове носіння }\end{array}$ & $\begin{array}{c}\text { Зростання опору } \\
\text { диханню }\end{array}$ & $\begin{array}{l}\text { Ужити новий фільтрувальний } \\
\text { респіратор }\end{array}$ \\
\hline
\end{tabular}

Далі визначаємо, який саме фільтрувальний пристрій будемо використовувати протиаерозолльний, протигазовий чи комбінований. В даному випадку небезпечними $€$ тверді частинки вугільного пилу, тому зупинимось на протиаерозоль-ному респіраторі з фільтром, який захищає від твердих частинок. Клас захисту вибраного фільтрувального ЗІЗОД визначимо, виходячи 3 формули [20]:

$$
\mathrm{K}_{3}>\mathrm{K}_{3 Б},
$$

де $K_{3}$ - коефіцієнт захисту респіратора, $\mathrm{K}_{3 Б}=\frac{\mathrm{C}_{3}}{\text { ГдК }}-$ коефіцієнт забруднення робочої зони; $C_{3}$ - концентрація аерозолів у робочій зоні.
Враховуючи, що ГДК для вугільного пилу складає $10 \mathrm{mr} / \mathrm{M}^{3}$, то КзБ при запиленості 30 $\mathrm{Mr} / \mathrm{M}^{3}$ дорівнює - 3, отже нам потрібний респіратор з фільтром другого класу захисту. У виробників ЗІЗОД вони маркуються як FFP2.

Наступний кроком $€$ вибір ЗІзОД за способом надходження: примусове чи самовисмоктування. Фільтрувальні респіратори 3 примусовою подачею повітря 3 здебільшого використовують для захисту від токсичного пилу, коли необхідно створити у підмасковому просторі надлишковий тиск, який завадив потраплянню шкідливої речовини крізь нещільності смуги обтюрації. В даному випадку вугільний пил не токсичний, тому зупинимось на фільтрувальних респіраторах з природньою подачею повітря. 
Таблиця 5. - Нова класифікація фільтрувальних зІзОД

\begin{tabular}{|c|c|c|}
\hline \multicolumn{2}{|r|}{ Класифікація ЗІзОД } & $\begin{array}{l}\text { Маркування за EN } \\
529\end{array}$ \\
\hline Відділ & Фільтруючі & $\mathrm{F}$ \\
\hline \multicolumn{3}{|c|}{ За функціональним призначенням } \\
\hline \multirow{3}{*}{ Підвідділ } & $\begin{array}{l}\text { - проаерозольні (захищають від твердих і рідких аеродисперсних } \\
\text { частинок) }\end{array}$ & $P(S, S L)$ \\
\hline & - протигазові (захищають від токсичних газів і парів) & $\begin{array}{l}A, B, E, K, A X, N O \\
S X\end{array}$ \\
\hline & $\begin{array}{l}\text { - газопилозахисні (захищають від аеродисперсних твердих і рідких } \\
\text { частинок, токсичних газів і парів) }\end{array}$ & P + гази і пари \\
\hline \multicolumn{3}{|c|}{ За есрективністю захисту } \\
\hline \multirow{3}{*}{ Група } & - низька; & від 1 до 4 ГДк \\
\hline & - середня; & від 2 до 12 гдк \\
\hline & висока & від 3 до 50 гдк \\
\hline \multicolumn{3}{|c|}{ За санітарними вимогами } \\
\hline \multirow{2}{*}{ Підгрупа } & - одноразові (з фільтруючою півмаскою); & - \\
\hline & - багаторазові (з фільтрами або патронами, що замінюються. & - \\
\hline \multicolumn{3}{|c|}{ За способом надходження повітря у підмасковий простір } \\
\hline \multirow{2}{*}{ Вид } & - природне; & $\mathrm{F}$ \\
\hline & - примусове. & TM \\
\hline \multicolumn{3}{|c|}{$\begin{array}{l}\text { з урахуванням вимог щодо ергономічності і забезпечення безпечної праці користувачів при } \\
\text { експлуатації фільтрувальних респіраторів, зокрема: }\end{array}$} \\
\hline \multirow{3}{*}{ Підвид } & $\begin{array}{l}\text { - масок (повнолицевих, півмасок, четверть масок, у тому числі з } \\
\text { пристроями для переговорів); }\end{array}$ & $\begin{array}{l}\text { Розміри масок } \\
\text { S- малий }\end{array}$ \\
\hline & - фільтрів; & М - середній \\
\hline & - наголів'я. & $\begin{array}{l}\mathrm{L}-\text { великий } \\
\mathrm{NR}, \mathrm{R}\end{array}$ \\
\hline \multicolumn{3}{|c|}{ З урахуванням досконалості конструкції респіраторів або/і їх складових щодо фізіологічних вимог: } \\
\hline \multirow{4}{*}{ Різновид } & $\begin{array}{l}\text { - масок (без клапанів, з клапанами видиху, клапанами вдиху і } \\
\text { видиху) }\end{array}$ & \multirow{4}{*}{$\mathrm{FF}$} \\
\hline & $\begin{array}{l}\text { - обтюраторів (одно- і двоскладчасті, з U-подібною складкою, } \\
\text { надувні); }\end{array}$ & \\
\hline & - клапанів видиху (грибкові, дискові, пелюсткові); & \\
\hline & - наголів'я (одно- і двосмужкове). & \\
\hline
\end{tabular}

Вибір лицевої частини фільтрувального респіратора залежить від подразнення аерозолем очей, якщо воно $\epsilon$ то необхідна маска, при відсутності можна скористатись півмаскою. 3 усіх наявних у виробників фільтрів 2-го класу захисту зупинимось на тих, які мають найнижчий опір, оскільки в умовах тяжкої праці, великої вологості повітря (> 80\%) та концентрації пилу ( $\left.\geq 500 \mathrm{mr} / \mathrm{m}^{3}\right)$ користувачу, зокрема шахтарю, доведеться часто замінювати гофровані фільтри 3-4 рази за зміну через швидке зростання опору дихання внаслідок «цементації» пилу при взаємодії 3 вологою, що видихається. Крім того, висока температура і вологість повітря сприятимуть накопиченню вологи у підмасковому просторі, тому необхідна півмаска з клапанами вдихання і видихання.

Останнім кроком $€$ перевірка сумісності вибраного фільтрувального респіратора 3 користувачем за медичними показниками i пристосованості до його обличчя. Оцінка 
досконалості ЗІзОД і їх компонентів здійснюється за якісними і кількісними показниками. Зокрема, досконалість конструкцій фільтрувальних респіраторів оцінюється за щільністю прилягання півмасок до обличчя користувача по смузі обтюрації, оскільки «підсмоктування» (проникнення) шкідливих токсичних аерозолів (аеродисперсних частинок, газів і парів) в підмасковий простір відбувається, головним чином, крізь щілини між обличчям і поверхнею притискання обтюратора.

Відомі способи якісної оцінки щільності прилягання напівмасок фільтрувальних респіраторів до обличчя користувача ґрунтуються на органолептичному сприянні запаху органами дихання частинок (сахарин, бітрекс, $\mathrm{NH}_{4} \mathrm{Cl}$, ізоамілацетат та ін.), газів або парів $\left(\mathrm{NH}_{3}, \mathrm{SO}_{2}, \mathrm{H}_{2} \mathrm{~S}\right.$, легколетючі органічні сполуки та ін.), що «проскочили» у підмасковий простір фільтрувального респіратора, а також візуальній індикації частинок (пил вугілля, фарбники та ін.), що осіли на смузі обтюрації. До речі, досвідчений інженерно-технічний персонал i робітники, 3 чутливими рецепторами органів дихання, здатні ідентифікувати місцеположення щілин за локальними градієнтами температури на шкіряному покриві. Нажаль, таких «умільців» замало.

Очевидні недоліки якісних способів оцінки щільності прилягання обтюратора фільтрувального респіратора до обличчя користувача обумовлені наступним: по-перше, запах користувачем респіратора сприймається, коли досягається його особистий поріг чутливості токсиканту, що накопичується у підмасковому просторі за певний час експлуатації фільтрувального респіратора, але питання щодо місцезнаходження щілини у цьому разі залишається без відповіді; по-друге, візуалізація щілини, хоча i дозволяє ідентифікувати їі місцезнаходження, - занадто довготривалий процес і, до того ж, одержання результату досягається лише post faktum - після спрацьовування фільтрувального респіратора.

Зі зрозумілих причин, більш інформативні кількісні способи оцінки якості фільтрувальних респіраторів. Наприклад, на підставі даних щодо співвідношення концентрації токсикантів у підмасковому просторі фільтрувального респіратора і робочій зоні, які визначаються згідно ДСТУ ЕN 149:2017 за допомогою лічильників аеродисперсних частинок i газоаналізаторів, ЗІЗОД надається відповідний клас захисту. Згідно зі способом [19] для визначення місць «підсмоктування» забрудненого повітря по смузі обтюрації використовують спеціальну камеру, обладнану дозатором тест-речовини (флюорохромного порошку), а візуалізацію місць осаджування аеродисперсних частинок флюорохромного порошку на смузі обтюрації визначають за фотолюмінесценцією частинок при їх опроміненні ультрафіолетовим світлом. Загальний недолік кількісних способів необхідність у відносно коштовних приладах і обладнанні та спеціально підготовленому персоналі, неможливість масових випробувань у виробничих умовах підприємства. Тому пропонується до використання більш швидкий спосіб перевірки щільності прилягання півмасок фільтрувального респіратора до обличчя користувача шляхом термографування поверхні обтюратора за допомогою тепловізора і подальшого визначення місць підсмоктування аерозолю за інтенсивністю теплового випромінювання поверхні обтюратора у інфрачервоному діапазоні або інтенсивністю відображення теплового поля поверхні обтюратора на дисплеї тепловізору [20]. Для одержання необхідних відомостей, півмаску, встановлену на обличчі 3 дотриманням правил виробника та елементарної перевірки правильності ії одягання [21], утримували на обличчі одну хвилину, а потім здійснювали зйомку і аналіз одержаної термограми обтюратора. Місця нещільного прилягання півмаски до обличчя легко визначаються: на термограмі вони, на відміну від місць щільного прилягання обтюратора до обличчя, мають менш інтенсивне забарвлення, оскільки нагріваються підчас контакту з обличчям до меншої температури (мал. 2). 


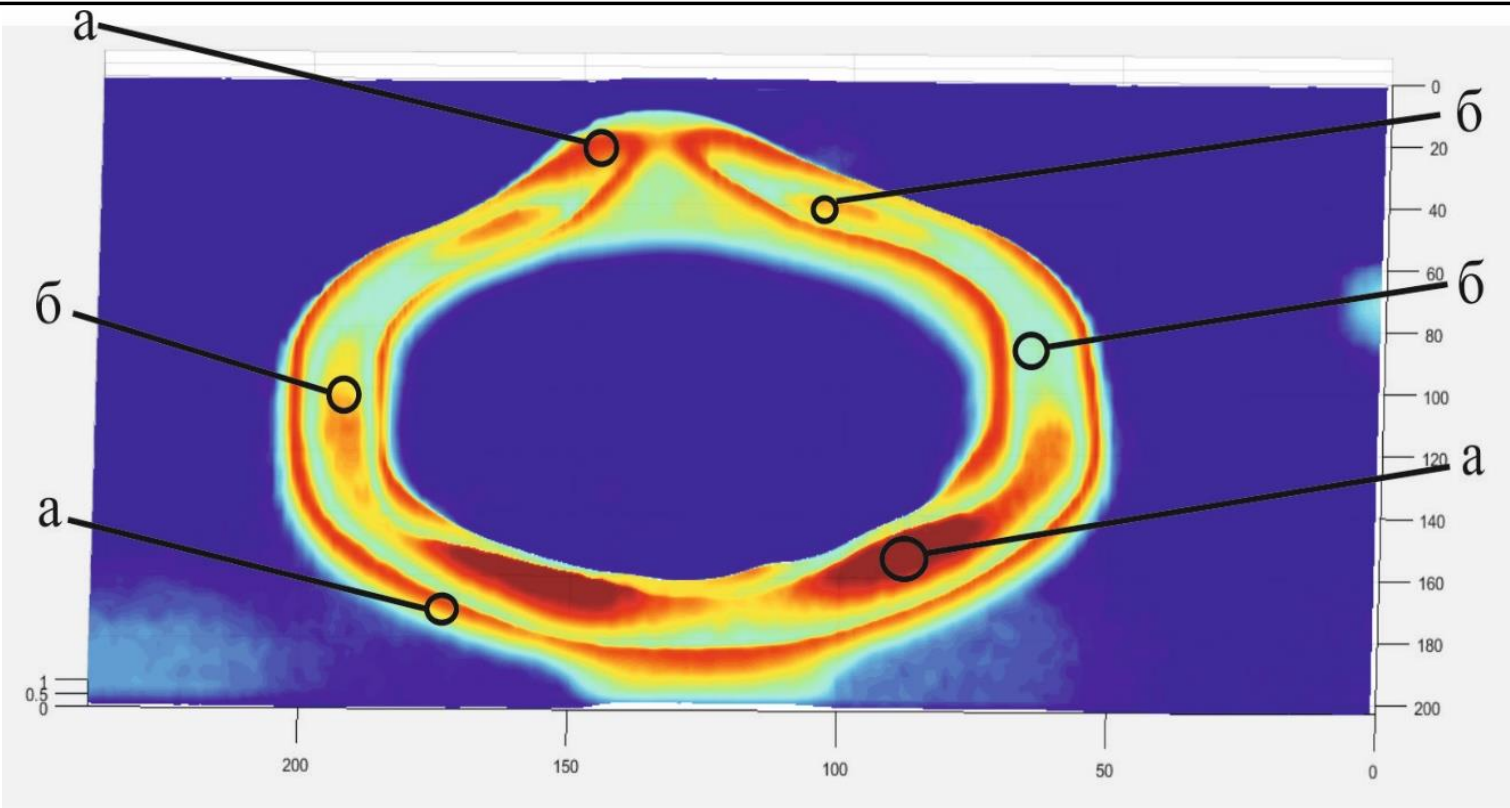

Мал. 2. Термограма обтюратора півмаски фільтрувального респіратора

а - при щільному приляганні до обличчя (червоне забарвлення); б - при нещільному приляганні до обличчя забарвлення змінюється від світло-зеленого до помаранчевого в залежності від величини зазору між обличчям і обтюратором півмаски

Особливу увагу необхідно приділити визначенню терміну захисної дії фільтрів. Якщо для протипилового фільтра він здебільшого визначається ускладненням дихання, то у протигазового залежить від багатьох параметрів, зокрема [28]: хімічного складу (суміші) повітряних забруднень; концентрацій повітряних забруднень; умов застосування (витрата повітря, його температура і вологість); властивостей фільтра (його форма, кількість і властивості сорбенту). У фільтрі використовується спеціальний сорбент, який знаходиться в корпусі фільтрувальної коробки у вигляді гранул. Молекули шкідливої речовини стикаються 3 поверхнею сорбенту i «прилипають» до неї, утворюючи міцний зв'язок за рахунок добавок спеціальних хімічних елементів. У міру насичення сорбент поступово втрачає здатність поглинати домішки, що призводить до потрапляння небезпечних речовин у більш глибші шари сорбенту. При цьому концентрація шкідливих речовин в очищеному повітрі, яке потрапляє через фільтр у підмасковий простір фільтрувального респіратора або протигазу, поступово буде збільшуватись і через деякий час перевищить ГДК. Отже, заміна протигазового фільтра повинна проводитися не пізніше цього моменту.

Відповідно до Правил вибору та застосування ЗІЗОД (НПАОП 0.00-1.04-07), затверджених наказом Державного комітету України з промислової безпеки, охорони праці та гірничого нагляду від 28 грудня 2007 p. №331, та рекомендацій вітчизняних розробників основним критерієм необхідності заміни фільтра є запах шкідливої речовини у підмасковому просторі фільтрувального респіратора. Однак дослідження показали, що використання суб'єктивної реакції органів чуття на появу запаху під маскою $є$ ненадійним способом [29] - у частини газів відсутній запах при концентраціях, які значно перевищують гранично допустимі значення.

За даними "ЗМ Respirator Selection Guide" (2018) не можна використовувати органи чуття людини як засіб визначення терміну захисної дії фільтрів, оскільки концентрація, за якої люди (в середньому) відчувають присутність діоксиду хлору, перевищує ГДК у 90 разів, а у пентаборана - у 190 разів [30]. За меншої концентрації перевищення ГДК 
суб'єктивна реакція органів чуттів може збільшити «термін служби» фільтрів до нескінченності. Так з 600 шкідливих речовин більше 60 не мають попереджувальних властивостей, а для 110 він зовсім не встановлений. Тому у США з 1996 р. в стандарті з охорони праці, який регулює порядок вибору і організації застосування зІзод, від роботодавця вимагають використовувати більш надійні способи (п. 1910.134 (d) (3) (i) (B) Standards 29 CFR 1910.134 "Respiratory Protection" (далі - 29 CFR 1910.134). Аналогічні вимоги також містяться і в п. А.2.4.3 EN 529:2005.

Реакція людини на запах індивідуальна і може залежати від різних обставин. Вважається, що поріг сприйняття запаху у $95 \%$ людей знаходиться в межах від 1/16 до 16 від «середнього» значення [28-30]. Тоді як у 2,5\% він перевищує середнє значення більш ніж в 16 разів. Тобто, якщо в середньому люди реагують на запах хлороформу при концентрації $\approx 1$ ГДК, частина 3 них ніяк не відреагує при сильному їі перевищенні. Також встановлено, що сприйняття залежить ще й від того, скільки уваги приділяється роботі, а також від стану здоров'я (застудні захворювання тощо). Деякі речовини при поступовому збільшенні концентрації (як і відбувається при насиченні сорбенту) викликають «звикання»: якщо на запах сірководню люди реагують при концентрації в 1000 разів меншою ГДК, то при поступовому ії збільшенні вони вже не будуть реагувати на небезпечне перевищення. Крім того, при тривалому стажі роботи в забрудненій атмосфері, через вплив газоподібних речовин при невеликій концентрації, може відбутися послаблення чутливості до цих речовин.

В цілому в США та Європі і раніше (в 70-і роки) вважали використання особистої реакції робочого для визначення терміну служби будь-якого протигазового фільтра ненадійним способом. Пізніше і зовсім заборонили користуватися ним, оскільки наукою були запропоновані більш надійні рішення: розрахунок захисної дії за допомогою комп'ютерних програм; використання індикаторів - активних "End of Service Life Indicator (ESLI)" та пасивних (за зміною забарвлення спеціальних поглиначів в міру насичення коробки шкідливим газом). Нині американський роботодавець зобов'язаний замінювати фільтри або за розкладом, що складається на основі визначення терміну служби фільтра 3 урахуванням конкретних умов використання, або за показаннями індикаторів. Складання розкладу відбувається за результатами лабораторних випробувань фільтра, які проведені з імітацією виробничих умов.

\section{Висновки}

Зрозуміло, що крім правильного вибору фільтрувального респіратора, до якого можна залучити досвідчених фахівців, наприклад 3 інституту промислової гігієни праці, які розуміються на технічних характеристиках фільтрувальних респіраторів і процедурі встановлення величин професійних ризиків їх вибору і експлуатації, важливо забезпечити вирішення організаційних питань - основним з яких $є$ заохочення користувачів їх правильно використовувати, що впливає на успішне виконання програми респіраторного захисту. Будь-який ЗІзОД $\epsilon$ додатковим навантаженням на користувача при виконанні їм професійної діяльності. Його величина, в значній мірі залежить від шкідливих факторів і запроваджених інших загальних засобів захисту. Якщо виникає необхідність у використанні фільтрувальних респіраторів, то користувачі повинні розуміти всю відповідальність при відмові від їх використання, настання професійного захворювання та погіршення якості життя, економічні втрати пов'язані 3 лікуванням. Важливо, щоб вони розуміли характер небезпеки та сприймали їі усвідомлюючи що перенесені незручності ні що у порівнянні із захворюванням. Це зумовить відповідально відноситись і до вибору і до застосування фільтрувальних респіраторів.

Важливо для правильного і своєчасного застосування ЗІЗОД донести до користувачів 
можливі ризики для здоров'я при не правильному використанні ЗІЗОД та провести відповідні тренування, які передбачають вивчення складових частин 3ІЗОД, правильне одягання, попереднє носіння для звикання та оцінки зручності, ознайомлення з діями під час надзвичайних ситуацій. Тренування необхідно проводити регулярно і його програма оновлюватись кожного року.

Встановлено, що навіть добросовісне виконання процедури вибору фільтрувальних респіраторів за ДСТУ ЕN 529:2006 не гарантує ефективний захист органів дихання користувача, оскільки розробники не передбачили про те, що їх вибір потрібно здійснювати, перш за все, відповідно до класифікації, враховуючи при цьому технічні характеристики фільтрувальних респіраторів і особливості антропометричних розмірів обличь у користувачів різних національностей, статі та вікових груп.

Запропоновано рекомендації щодо зменшення щодо усунення ризиків професійних захворювань внаслідок помилок при виборі і експлуатації фільтрувальних респіраторів, які можна використати для здійснення розрахунку ризиків професійних захворювань одним із придатних методів згідно з ДСТУ IEC/ISO 31010:2013. Зазначимо, що організація оцінки ризиків професійних захворювань як при виборі, так і при експлуатації фільтрувальних респіраторів - обов'язок роботодавця, а контроль за сумлінним виконанням рекомендацій по ефективному використанню фільтрувальних респіраторів повинні здійснювати робітники відділів охорони праці підприємства.

Визначено, що застосування фільтрувальних респіраторів пов'язано з додатковим потенційним ризиком професійних захворювань і гострих отруєнь через завищений термін захисної дії фільтрів, який визначається без урахування реальної концентрації і умов праці за рекомендаціями наведеними у відповідних нормативних законодавчих документах. Рекомендується використовувати протигазові фільтрі 3 індикаторами закінчення строку експлуатації або звертатись до виробників з проханням визначити їх з урахуванням специфіки їх виробництва.

Розроблено нову класифікацію ЗІЗОД, яка заповнює існуючі прогалини у вітчизняному законодавстві та дозволяє 3 розумінням розробити послідовність дій при виборі ЗІЗОД. Вона $\epsilon$ першою спробою у розподілі всіх існуючих ЗІзОД за зрозумілим ієрархічним порядком підлеглості нижчих ланок вищим, починаючи з відділу - фільтрувальні ЗІЗОД і закінчуючи різновидом - за ступенем досконалості конструкції респіраторів або/і їх складових щодо фізіологічних вимог користувача.

\section{Список використаних джерел}

1. Ромась М.Д., Цибульська О.В. Щодо визначення потреби в засобах індивідуального захисту для працівників на виробництві. Проблеми охорони праці в Україні. 2015. №29. С. 88-102.

2. Правила вибору та застосування засобів індивідуального захисту органів дихання. Сайт Головного управління Держпраці у Харківській області. URL: https://www.kh.dsp.gov.ua/новини/Правил а-вибору-та-застосування-засо/ (дата звернення 15.06.2020).

3. Засоби індивідуального захисту органів дихання. Сайт Державної установи
"Харківський обласний лабораторний центр Міністерства охорони здоров'я України". URL: https://labcenter.kh.ua/ $? p=10840$ (дата звернення 15.06.2020).

4. Засоби індивідуального захисту органів дихання. Сайт Служби охорони праці. URL: https://www.sop.com.ua/article/808-zasobindivdualnogo-zahistu-organv-dihannya (дата звернення 15.06.2020).

5. Стрилец В.М. Особенности выбора средств индивидуальной защиты для работы спасателей в условиях, которые существенно отличаются от наихудших условий 
пожара. Системи озброєння і військова техніка. 2014. № 4(40). С. 150-153.

6. Петрачкова Н.М. Анализ эффективности средств индивидуальной защиты горнорабочих в зимних условиях. Научные исследования и разработки молодых ученых. 2014. №1. С. 106-109.

7. Golinko V.I., Cheberyachko S.I., Cheberyachko Y.I., Yavorska O.O., Tykhonenko V.V. Improving efficiency of dust mask use in mining: monograph. Donetsk: NMU, 2014. $100 \mathrm{p}$.

8. Вознесенский В. В. Средства защиты органов дыхания и кожи. Москва: Военные знания. 2011. 80 c.

9. Cai M., Li H., Shen S., Wang Y., Yang Q. (2018) Customized design and 3D printing of face seal for an N95 Filtering Facepiece Respirator. Journal of Occupational and Environmental Hygiene. No. 15(3). P. 226-234. DOI: 10.1080/15459624.2017.1411598.

10. Gutierrez A.M., Galang M.D., Seva R.R., Lu M.C., Ty D.R.S. Designing an improved respirator for automotive painters. International Journal of Industrial Ergonomics. 2014. No. 44(1). P. 131-139. DOI: 10.1016/j.ergon.2013.11.004.

11. Lei Z., Yang J., Zhuang Z. (2012) Headform and N95 Filtering Facepiece Respirator Interaction: Contact Pressure Simulation and Validation. Journal of Occupational and Environmental Hygiene. No. 9. P. 46-58. DOI: 10.1080/15459624.2011.63513.

12. Glomb S., Woschko D., Makhloufi G., Janiak C. (2017) Metal-Organic Frameworks with Internal Urea-Functionalized Dicarboxylate Linkers for $\mathrm{SO}_{2}$ and $\mathrm{NH}_{3}$ Adsorption. ACS Applied Materials \& Interfaces. No. 9(42). P. 37419-37434. DOI: 10.1021/acsami.7b10884.

13. Li Y., Guo Y., Zhu T., Ding S. (2016) Adsorption and desorption of $\mathrm{SO}_{2}, \mathrm{NO}$ and chlorobenzene on activated carbon. Journal of Environmental Sciences. No. 43. P. 128135. DOI: 10.1016/j.jes.2015.08.022.

14. Tan K., Zuluaga S., Gong Q., Gao Y., Nijem N., Li J., Thonhauser T., Chabal Y.J. (2015) Competitive co-adsorption of $\mathrm{CO}_{2}$ with $\mathrm{H}_{2} \mathrm{O}$,
$\mathrm{NH}_{3}, \mathrm{SO}_{2}, \mathrm{NO}, \mathrm{NO}_{2}, \mathrm{~N}_{2}, \mathrm{O}_{2}$, and $\mathrm{CH}_{4}$ in M-MOF$74(\mathrm{M}=\mathrm{Mg}, \mathrm{Co}, \mathrm{Ni})$ : the role of hydrogen bonding. Chemistry of Materials. No. 27(6). P. 2203-2217. DOI: 10.1021/acs.chemmater. 5 b00315.

15. Ye C.Z., Ariya P.A. (2015) Co-adsorption of gaseous benzene, toluene, ethylbenzene, $\mathrm{m}$ xylene (BTEX) and $\mathrm{SO} 2$ on recyclable $\mathrm{Fe} 3 \mathrm{O} 4$ nanoparticles at $0-101 \%$ relative humidities. Journal of Environmental Sciences. No. 31. P. 164-174. DOI: 10.1016/j.jes.2014.10.019.

16. Lei Z., Yang J., Zhuang Z. (2014) A Novel Algorithm for Determining Contact Area Between a Respirator and a Headform. Journal of Occupational and Environmental Medicine. No. 11(4). P. 227-237. DOI: 10.1080/15459624.2013.858818.

17. Vinothkumar N., Varatharasan V. (2017) CFD flow simulation of protection layer in air pollution mask. International Journal of Advanced Research in Basic Engineering Sciences and Technology. No. 3(24). P. 198304. ISSN (PRINT): 2395-695X.

18. ДСТУ EN 529:2006. Засоби індивідуального захисту органів дихання. Рекомендації щодо вибору, використання, догляду і обслуговування. Настанова. Чинний від 01.10.2007. Київ, 2008. 38 с. URL: https:// http://online.budstandart.com/ua/catalog/d oc-page?id_doc=54667 (дата звернення 15.06.2020).

19. Гудков С.В., Дворецкий С.И., Путин С.Б., Таров В.П. Изолирующие дыхательные аппараты и основы их проектирования. Учебное пособие. Москва: Машиностроение. 2008. 188 c.

20. Aneziris O.N., Papazoglou I.A., Konstantinidou M., Nivolianitou Z. (2014) Integrated risk assessment for LNG terminals. Journal of Loss Prevention in the Process Industries. No. 28. P. 187-204. DOI: 10.1016/j.jlp.2013.07.014.

21. Нагорна А.М., Вітте П.М., Соколова М.П., Кононова І.Г., Орехова О., Мазур В.В. Оцінка ризику розвитку професійних захворювань у працівників металургійної, вугільної промисловості та машино- 
будування України. Український журнал з проблем медицини праці. 2012. №3(31). С. 3-13.

22. Kirillov V.F., Bunchev A.A., Chirkin A.V. (2013) On means of individual protection of respiratory organs of the workers (literature review). FGBU "Scientific and research Institute of Labour Medicine" of Russian Academy of Medical Sciences Labour Medicine and Industrial Ecology. 2013. No. 4. P. 25-31.

23. Eraiyanbu P., Anbalagan M., Prabhu R, Sirajudeen I., Satheeshkumar P. (2017) Hazard identification \& risk assessment with human error asnalysis method in asutomotive industry. International Journal of Innovative Research in Science, Engineering and Technology. No. 6(8). P. 131-145. ISSN (Print): 2347-6710.

24. Kovacs L., Immermann A., Brockmann G. (2006) Three-dimensional recording of the human face with a 3D laser scanner. Journal of Plastic Reconstructive \& Aesthetic Surgery. No. 59. P. 1193-1202. DOI:10.1016/j.bjps. 2005.10.025.

25. Капцов В.А., Чиркин А.В. Невесомый порог. Проблемы использования противогазных СИЗ органов дыхания. Безопасность и охрана труда. Нижний Новгород: БИОТа. 2015. 1. С. 59-63.

26. Bollinger, N. NIOSH respirator selection logic. U.S. Department of Health and Human Services (U.S. HHS), National Institute for
Occupational Safety and Health (NIOSH). Publication No. 2005-100, 11. Cincinnati, OH: NIOSH Publication Dissemination; 2004.

27. Checky M., Frankel K., Goddard D., Johnson E., Thomas J.C., Zelinsky M., Javner C. Evaluation of a passive optical based end of service life indicator (ESLI) for organic vapor respirator cartridges. Journal of Occupational and Environmental Hygiene. 2016. No. 13(2). P. 112-120. DOI: 10.1080/15459624.2015. 1091956.

28. Васильєв $€$. В., Гизатуллин Ш. Ф., Спельнікова М. І. Проблема вибору і використання протівогазоаерозольних фільтруючих напівмасок. Довідник спеціаліста з охорони праці. 2014. №12. С. 51-55.

29. ДСТУ 7239:2011 Система стандартів безпеки праці. Засоби індивідуального захисту загальні вимоги та класифікація. Чинний від 2011-08-01. Київ, 2011. Держспоживстандарт України. 8 с. URL: http://online.budstandart.com/ua/catalog/d oc-page.html?id_doc=51051 (дата звернення 15.06.2020).

30. ДСТУ ЕN 133:2005 Засоби індивідуального захисту органів дихання. Класифікація. Чинний від 2006-07-01. Київ, 2006. ДЕРЖСПОЖИВСТАНДАРТ України. 15 с. URL: http://online.budstandart.com/ua/ catalog/doc-page?id_doc=54221 (дата звернення 15.06.2020).

\title{
Выбор эффективных фильтрующих респираторов. Проблемы
}

\section{И возМОЖности}

\section{Сергей Чеберячко * А; Олег Дерюгин А; Владимир Мирненко ${ }^{\text {; }}$ Наталья Бородина ${ }^{\mathrm{C}}$}

*Corresponding author: д.т.н., профессор, профессор кафедры охраны труда и гражданской безопасности, e-mail: sicheb@ukr.net, ORCID: 0000-00033281-7157

А Национальный технический университет «Днепровская политехника», пр-кт Дмитрия Яворницкого, 19, г. Днепр, 49005, Украина,

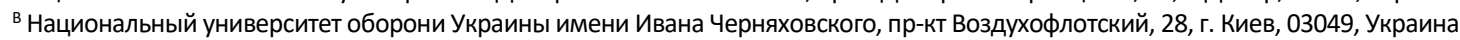

с Белоцерковский институт непрерывной профессионального образования, ул. Леваневского, 54/2, г. Белая Церковь, 09100, Украина

\begin{abstract}
Аннотация
Целью работы является раскрытие возможностей для обеспечения выбора качественного фильтрующего респиратора, который соответствует условиям труда и
\end{abstract}


антропометрическим параметрам лица пользователей. Установлено, что критическими вопросами для обеспечения надежной защиты пользователей при выполнении профессиональной деятельности с использованием средств индивидуальной защиты органов дыхания, не отражены в соответствующих нормативных документах процедуры оценки рисков, учета особенностей условий выполняемой работы, проверка соответствия полумаски фильтрующего респиратора антропометрическим параметрам лица пользователя, учет срока защитного действия фильтров. Предложено проводить оценку рисков профессиональных заболеваний при выборе и эксплуатации фильтровальных респираторов одним из методов в соответствии с требованиями ДстУ IEC/ISO 31010: 2013. Даны рекомендации по устранению возможных ошибок во время этого процесса для уменьшения уровня риска возникновения профессионального заболевания. Разработана новая классификация фильтрующих средств индивидуальной защиты органов дыхания, которая позволяет провести выбор с учетом особенностей условий выполняемой работы. Показано, что с помощью термографирования полосы обтюрации полумаски фильтрующего респиратора можно установить ее соответствие антропометрическим параметрам лица пользователя. Рекомендуется проводить замену фильтров, исходя или из расчета срока защитного действия в соответствии с особенностями условий выполняемой работы или использовав фильтры с активными/пассивными индикаторами.

Ключевые слова: средства индивидуальной защиты органов дыхания, фильтрующий респиратор, профессиональное заболевание, риск, предельно допустимая концентрация, вредных веществ.

\title{
Selection of effective filter respirators. Challenges and opportunities
}

\author{
Serhii Cheberiachko * A; Oleg Deryugin A; Volodymyr Mirnenko ${ }^{\text {B; }}$ \\ Nataliia Borodina ${ }^{C}$ \\ *Corresponding author: Doctor of Technical Science (D.Sc.), Professor, Professor of the Department of Labour Protection and Civil Safety, \\ e-mail: sicheb@ukr.net, ORCID: 0000-0003-3281-7157 \\ A Dnipro University of Technology, 19, Dmytra Yavornytskoho ave., Dnipro, 49005, Ukraine,

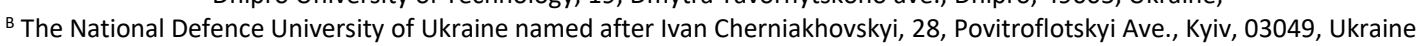 \\ ' Bilotserkivsky Institute of Continuous Professional Education, 54/2, Levanevska, str., Bila Tserkva, 09100, Ukraine
}

\begin{abstract}
The aim of this paper is to reveal the possibilities to ensure the choice of quality filter respirator that meets the working conditions and anthropometric parameters of user. It is established that the critical issues to ensure reliable protection of user during the performance of professional activities with the use of devices of individual protection of respiratory organs, which are not disclosed (not reflected) by the relevant regulations, the procedure of risk assessment, based on work conditions, verification of compliance of the filter respirator half-mask to anthropometric parameters of user's face, taking into account the duration of filters protective action.

It is shown that according to the normative acts of the organization for the assessment of the risks of occupational diseases both in the choice and operation of filter respirators is the responsibility of the employer, and the monitoring of faithful implementation of the recommendations on the effective use of filter respirators must be carried out by the departments of labor protection of the enterprise. It is proposed to assess risks of occupational diseases during the selection and operation of the filtering respirators one of the methods in accordance with the requirements of DSTU IEC/ISO 31010:2013. The recommendations on elimination of possible mistakes during this process to reduce the risk of occupational disease are provided. The new classification of filtering means of individual protection of respiratory organs was developed, which allows carrying out selection taking into account the peculiarities of conditions of work. It is shown that by using thermography
\end{abstract}


of obturate band of filter respirator half mask, you can set it according to anthropometric parameters of the user's face. It is recommended that you replace the filters or on the basis of calculation of term of protective action under the conditions or by using filters with active/passive indicators.

Keywords: personal protective equipment, occupational disease, risk, maximum permissible concentration of harmful substances.

\section{References}

1. Romas M. D., Tsybulska O. V. (2015) Shchodo vyznachennia potreby $\mathrm{v}$ zasobakh indyvidualnoho zakhystu dlia pratsivnykiv na vyrobnytstvi [Regarding the determination of the need for personal protective equipment for workers in the workplace]. Problemy okhorony pratsi v Ukraini. 2015. №29. S. 88-102. [in Ukraine]

2. Pravyla vyboru ta zastosuvannia zasobiv indyvidualnoho zakhystu orhaniv dykhannia [Rules for selection and use of personal respiratory protection]. Sait Holovnoho upravlinnia Derzhpratsi u Kharkivskii oblasti. URL: https://www.kh.dsp.gov.ua/novyny/ Pravyla-vyboru-ta-zastosuvannia-zaso/ (data zvernennia 15.06.2020). [in Ukraine]

3. Zasoby indyvidualnoho zakhystu orhaniv dykhannia [Respiratory protection]. Sait Derzhavnoi ustanovy "Kharkivskyi oblasnyi laboratornyi tsentr Ministerstva okhorony zdorovia Ukrainy". URL: https:// https://labcenter.kh.ua/?p=10840 (data zvernennia 15.06.2020). [in Ukraine]

4. Zasoby indyvidualnoho zakhystu orhaniv dykhannia [Respiratory protection]. Sait Sluzhby okhorony pratsi. URL: https://www.sop.com.ua/article/808-zasobindivdualnogo-zahistu-organv-dihannya (data zvernennia 15.06.2020). [in Ukraine]

5. Strylets V.M. (2014) Osobennosty vыbora sredstv yndyvydualnoi zashchytb dlia rabotb spasatelei v uslovyiakh, kotorbe sushchestvenno otlychaiutsia ot naykhudshykh uslovyi pozhara [Features of the choice of personal protective equipment for the work of rescuers in conditions that significantly differ from the worst fire conditions]. Systemy ozbroiennia i viiskova tekhnika. № 4(40). S. 150-153. [in Ukraine]

6. Petrachkova N.M. (2014) Analyz effektyvnosty sredstv indyydualnoi zashchyty hornorabochykh $v$ zymnykh uslovyiakh [Analysis of the effectiveness of personal protective equipment for miners in winter conditions]. Nauchnye issledovanyia $i$ razrabotki molodykh uchenykh. №1. S. 106109. [in Ukraine]

7. Golinko V.I., Cheberyachko S.I., Cheberyachko Y.I., Yavorska O.O., Tykhonenko V.V. (2014) Improving efficiency of dust mask use in mining: monograph. Donetsk: NMU, $100 \mathrm{~s}$. [in Ukraine]

8. Voznesenskyi V.V. Sredstva zashchyty orhanov dykhanyia i kozhy [Respiratory and skin protection]. M.: Voennye znaniya. $2011.80 \mathrm{~s}$.

9. Cai M., Li H., Shen S., Wang Y., Yang Q. (2018) Customized design and 3D printing of face seal for an N95 Filtering Facepiece Respirator. Journal of Occupational and Environmental Hygiene. No. 15(3). P. 226-234. DOI: 10.1080/15459624.2017.1411598.

10. Gutierrez A.M., Galang M.D., Seva R.R., Lu M.C., Ty D.R.S. (2014) Designing an improved respirator for automotive painters. International Journal of Industrial Ergonomics. No. 44(1). P. 131-139. DOI: 10.1016/j.ergon.2013.11.004.

11. Lei Z., Yang J., Zhuang Z. (2012) Headform and N95 Filtering Facepiece Respirator Interaction: Contact Pressure Simulation and Validation. Journal of Occupational and Environmental Hygiene. No. 9. P. 46-58. DOI: 10.1080/15459624.2011.63513.

12. Glomb S., Woschko D., Makhloufi G., Janiak C. (2017) Metal-Organic Frameworks with Internal Urea-Functionalized Dicarboxylate Linkers for $\mathrm{SO}_{2}$ and $\mathrm{NH}_{3}$ Adsorption. ACS Applied Materials \& Interfaces. No. 9(42). P. 37419-37434. DOI: 10.1021/acsami.7b10884.

13. Li Y., Guo Y., Zhu T., Ding S. (2016) Adsorption 
and desorption of $\mathrm{SO}_{2}, \mathrm{NO}$ and chlorobenzene on activated carbon. Journal of Environmental Sciences. No. 43. P. 128-135. DOI: 10.1016/j.jes.2015.08.022.

14. Tan K., Zuluaga S., Gong Q., Gao Y., Nijem N., Li J., Thonhauser T., Chabal Y.J. (2015) Competitive co-adsorption of $\mathrm{CO}_{2}$ with $\mathrm{H}_{2} \mathrm{O}$, $\mathrm{NH}_{3}, \mathrm{SO}_{2}, \mathrm{NO}, \mathrm{NO}_{2}, \mathrm{~N}_{2}, \mathrm{O}_{2}$, and $\mathrm{CH}_{4}$ in M-MOF$74(\mathrm{M}=\mathrm{Mg}, \mathrm{Co}, \mathrm{Ni})$ : the role of hydrogen bonding. Chemistry of Materials. No. 27(6). P. 2203-2217. DOI: 10.1021/acs.chemmater. 5 b00315.

15. Ye C.Z., Ariya P.A. (2015) Co-adsorption of gaseous benzene, toluene, ethylbenzene, $\mathrm{m}$ xylene (BTEX) and SO2 on recyclable $\mathrm{Fe} 3 \mathrm{O} 4$ nanoparticles at $0-101 \%$ relative humidities. Journal of Environmental Sciences. No. 31. P. 164-174. DOI: 10.1016/j.jes.2014.10.019.

16. Lei Z., Yang J., Zhuang Z. (2014) A Novel Algorithm for Determining Contact Area Between a Respirator and a Headform. Journal of Occupational and Environmental Medicine. No. 11(4). P. 227-237. DOI: 10.1080/15459624.2013.858818.

17. Vinothkumar N., Varatharasan V. (2017) CFD flow simulation of protection layer in air pollution mask. International Journal of Advanced Research in Basic Engineering Sciences and Technology. No. 3(24). P. 198304. ISSN (PRINT): 2395-695X.

18. DSTU EN 529:2006. Zasoby indyvidualnoho zakhystu orhaniv dykhannia. Rekomendatsii shchodo vyboru, vykorystannia, dohliadu i obsluhovuvannia. Nastanova. [Respiratory protection. Recommendations for selection, use, care and maintenance. Attitude] Chynnyi vid 01.10.2007. Kyiv, 2008. 38 s. URL: https:// http://online.budstandart.com/ua/catalog/do c-page?id_doc $=54667$ (data zvernennia 15.06.2020).

19. Hudkov S.V., Dvoretskyi S.Y., Putyn S.B., Tarov V.P. (2008) Izolyruiushchie dykhatelnye apparaty i osnovy ykh proektyrovanyia [Isolating breathing apparatus and the basics of their design]. Uchebnoe posobye. Moscow: Mashynostroenye. $188 \mathrm{~s}$.

20. Kirillov V.F., Bunchev A.A., Chirkin A.V. (2013) On means of individual protection of respiratory organs of the workers (literature review). FGBU "Scientific and research Institute of Labour Medicine" of Russian Academy of Medical Sciences Labour Medicine and Industrial Ecology. No. 4. P. 25-31.

21. Nahorna A.M., Vitte P.M., Sokolova M.P., Kononova I.H., Orekhova O., Mazur V.V. (2012) Otsinka ryzyku rozvytku profesiinykh zakhvoriuvan u pratsivnykiv metalurhiinoi, vuhilnoi promyslovosti ta mashynobuduvannia Ukrainy [Risk assessment of occupational diseases in workers of the metallurgical, coal industry and mechanical engineering of Ukraine]. Ukrainskyi zhurnal z problem medytsyny pratsi. №3(31). S. 3-13.

22. Aneziris O.N., Papazoglou I.A., Konstantinidou M., Nivolianitou Z. (2014) Integrated risk assessment for LNG terminals. Journal of Loss Prevention in the Process Industries. No. 28. P. 187-204. DOI: 10.1016/j.jp.2013.07.014.

23. Eraiyanbu P., Anbalagan M., Prabhu R, Sirajudeen I., Satheeshkumar P. (2017) Hazard identification \& risk assessment with human error asnalysis method in asutomotive industry. International Journal of Innovative Research in Science, Engineering and Technology. No. 6(8). P. 131-145. ISSN (Print): 2347- 6710.

24. Kovacs L., Immermann A., Brockmann G. (2006) Three-dimensional recording of the human face with a 3D laser scanner. Journal of Plastic Reconstructive \& Aesthetic Surgery. No. 59. P. 1193-1202. DOI:10.1016/j.bjps.2005. 10.025 .

25. Kaptsov V.A., Chyrkyn A.V. (2015) Nevesomyi porog. Problemy ispolzovaniya protyvohaznykh SIZ orhanov dykhanyia [Problems of using gas mask PPE of the respiratory system. Safety and labor protection]. Bezopasnost y okhrana truda. Nyzhnyi Novhorod: BYOTa. S. 59-63.

26. Bollinger, N. NIOSH respirator selection logic. U.S. Department of Health and Human Services (U.S. HHS), National Institute for Occupational Safety and Health (NIOSH). Publication No. 2005-100, 11. Cincinnati, OH: NIOSH Publication Dissemination; 2004.

27. Checky M., Frankel K., Goddard D., Johnson E., Thomas J.C., Zelinsky M., Javner C. Evaluation of a passive optical based end of service life 
indicator (ESLI) for organic vapor respirator cartridges. Journal of Occupational and Environmental Hygiene. 2016. No. 13(2). P. 112-120.

DOI:

10.1080/15459624.2015.1091956.

28. Vasyliev Ye.V., Hyzatullyn Sh.F., Spelnikova M.I. Problema vyboru i vykorystannia protivohazoaerozolnykh filtruiuchykh napivmasok [The problem of vibor and vikoristannya protivogazoazerozolnyh filtering napivmasok]. Dovidnyk spetsialista z okhorony pratsi. 2014. №12. S. 51-55.

29. DSTU 7239:2011 Systema standartiv bezpeky pratsi. Zasoby indyvidualnoho zakhystu zahalni vymohy ta klasyfikatsiia [System of labor safety standards. Personal protective equipment general requirements and classification]. Chynnyi vid 2011-08-01. Kyiv, 2011. DERZhSPOZhYVSTANDART Ukrainy. 8 s. URL: http://online.budstandart.com/ua/catalog/do c-page.html?id_doc=51051 (data zvernennia 15.06.2020).

30. DSTU EN 133:2005 Zasoby indyvidualnoho zakhystu orhaniv dykhannia. Klasyfikatsiia [Respiratory protection. Classification]. Chynnyi vid 2006-07-01. Kyiv, 2006. DERZhSPOZhYVSTANDART Ukrainy. $15 \mathrm{~s}$. URL: http://online.budstandart.com/ua/catalog/do c-page?id_doc $=54221$ (data zvernennia 15.06.2020). 